ZOOLOGIA 28 (6): 784-788, December, 2011

doi: $10.1590 /$ S1984-46702011000600012

\title{
Description of Sidneioides peregrinus sp. nov. (Tunicata: Ascidiacea: Polyclinidae): a possible exotic species in the Atlantic Ocean
}

\author{
Laura Pioli Kremer ; Rafael Metri² \& Rosana Moreira da Rocha ${ }^{3,4}$
}

\author{
${ }^{1}$ Instituto Federal de Santa Catarina. Rua Tijucas, 55, 88301-160 Itajaí, SC, Brazil. \\ ${ }^{2}$ Universidade Estadual do Paraná. Rua Comendador Correia Júnior 117, 83203-280 Paranaguá, PR, Brazil \\ ${ }^{3}$ Departamento de Zoologia, Universidade Federal do Paraná. Caixa Postal 19020, 81531-980 Curitiba, PR, Brazil. \\ ${ }^{4}$ Corresponding author. E-mail: rmrocha@ufpr.br
}

\begin{abstract}
Three species of Sidneioides Kesteven, 1909 were known until now, all of them from the western Pacific. Sidneioides peregrinus is a new species we found in Paranaguá Bay, southern Brazil. Diagnostic characteristics of the species are: colonies with 1-5 lobes, closely clumped, and attached by the entire basal area or by a common smaller area; seven to ten thin longitudinal fiber muscles (some branched) along the anterior two thirds of the thorax; no transverse muscle fibers; more than 30 tentacles of three orders forming one circle; pharynx with 10 to 12 rows of stigmata with 13 to 15 stigmata in each half row; bilobed anus at the level of the fourth or fifth row of stigmata; posterior abdomen not very elongated, oval, and joined to the abdomen by a narrow neck; numerous (> 30) testicular follicles; ovary with about 15 oocytes at about the ninth or tenth row of stigmata in the thorax; large number of embryos incubated in the atrial cavity in the right side of the thorax; larvae oval with a $0.65 \mathrm{~mm}$ long trunk, four clubshaped ectodermal ampullae in each side and three, linear and evenly spaced, adhesive papillae with thin stalks, two clusters of ectodermal vesicles, one postero-ventral (around 15 vesicles) and another antero-dorsal (around eight vesicles) between the ampullae and the oral siphon. This paper describes this new species and reports its occurrence in Brazil, where it is most likely introduced. The hypothesis that it is introduced is based on 1) it was never found in previous surveys, 2) in Brazil, it has a restricted and local distribution, 3) its type locality is near a major international port, and 4) the genus, prior to this description, had never been found in the Atlantic Ocean. Considering the great abundance found on the underside of natural boulders, it is imperative that S. peregrinus population growth be studied to evaluate the possibility of rapid distribution expansion.
\end{abstract}

KEY WORDS. Ascidian; Brazil; encrusting community; new species; species introduction.

Several colonies of Sidneioides Kesteven, 1909 were collected on the underside of boulders in Paranaguá Bay during recent surveys (early 2010). Sidneioides is in the Polyclinidae because it has gonads and the heart in the posterior abdomen, which is also a vegetative stolon (Котт 1992). The main apomorphy for this genus is the ovary in the middle of the right side of the thorax and not in the posterior abdomen, where it is found in the other genera (Котт 1992). Sidneioides comprised only three species until now: S. japonense Redikorzev, 1913 and S. snamoti (Oka, 1927), both from Japan, and the type species of the genus, S. tamaramae Kesteven, 1909, from Tamara Bay, Australia. Pérès (1957) described a putative fourth species, S. ivicense, from the Balearic Islands (western Mediterranean Sea), in a coralline bank about $60-70 \mathrm{~m}$ depth. However, the specimens studied by Pérès (1957) were immature and were considered Sidneioides based only on the lack of the dorsal atrial languet, after HARANT (1929), who believed this character to be diagnostic for the genus. Today, however, we know that these three species all have a dorsal atrial languet, even the type species S. tamaramae (Котт 1985). Additionally, A.A. RAmos-Esplá (unpub. data) has extensively surveyed the region in the 1980s and did not find this species again. Herein we describe Sidneioides peregrinus sp. nov. which is the first report of a species of this genus in the Atlantic Ocean.

\section{MATERIAL AND METHODS}

The Paranaguá Bay, state of Paraná $\left(25^{\circ} 31^{\prime} 13^{\prime \prime} \mathrm{S}, 48^{\circ} 28^{\prime}\right.$ $\left.41^{\prime \prime} \mathrm{W}\right)$, is a subtropical estuarine complex in southern Brazil. The salinity ranges between the minimum $12 \mathrm{ppt}$ in summer and maximum $34 \mathrm{ppt}$ in winter, with major variations due to daily tidal cycle, while the temperature ranges from $18^{\circ} \mathrm{C}$ in winter to $30^{\circ} \mathrm{C}$ in summer (Lana et al. 2001). While Cotinga island is in the euhaline sector of Paranaguá Bay, collecting sites were in a channel of brackish water of variable salinity due to the discharge of many rivers from the continent (Fig. 1). The northern tip of the island is less than $1.5 \mathrm{~km}$ from the port of Paranaguá. 


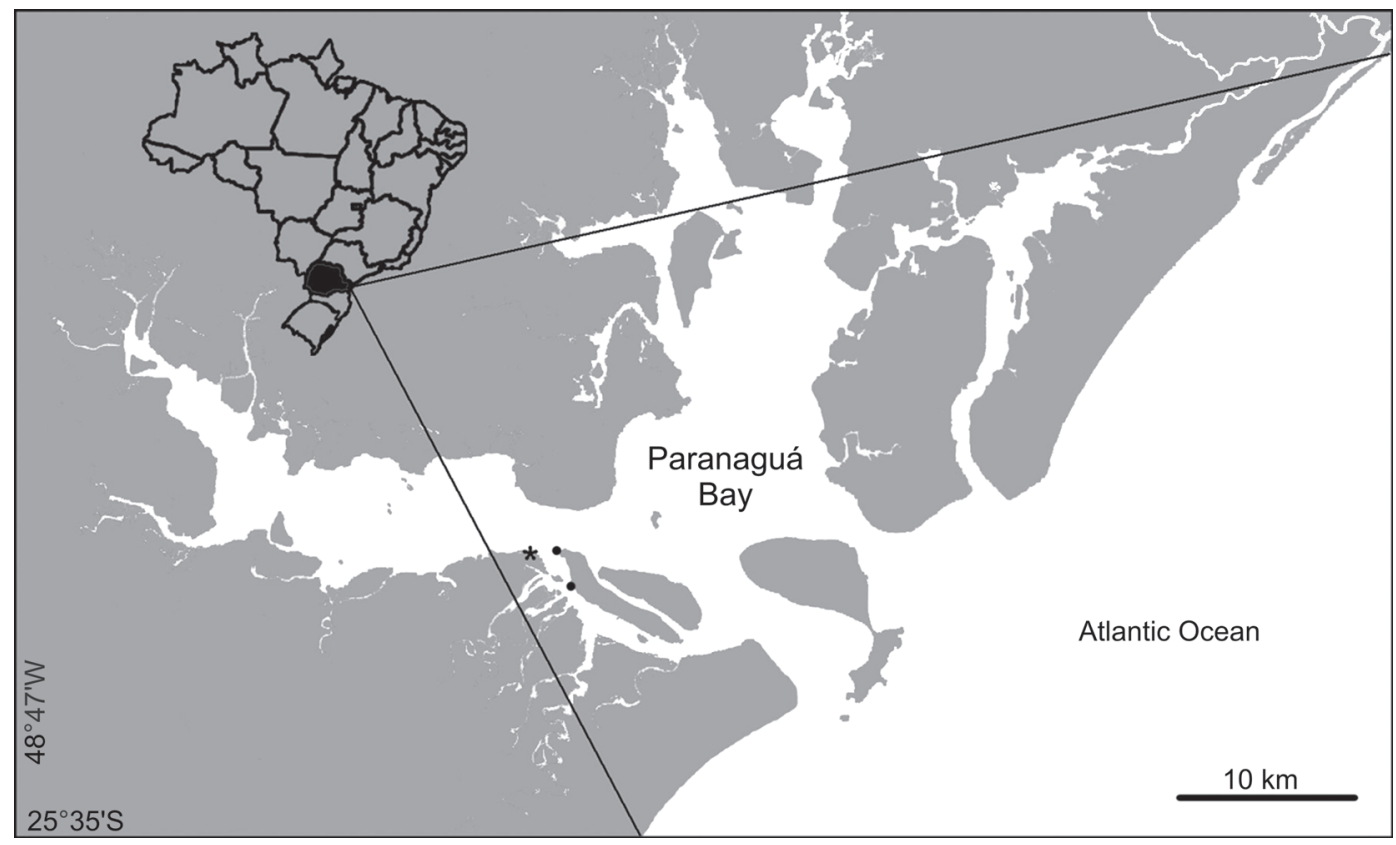

Figure 1. Map of Paranaguá Bay and its location in the state of Paraná (black area), Brazil (upper left). Dots represent surveyed locations at Cotinga island and the star, the Paranaguá Port.

Samples were collected in January and March 2010 during snorkeling and scuba diving. Animals were detached with knifes from the underside of boulders at 2-6 m depth. They were relaxed with menthol crystals for two hours and then preserved in neutral formalin $4 \%$ diluted in seawater. Lab dissections followed routine procedures (MоNNIOT et al. 1991).

\section{TAXONOMY}

\section{Sidneioides peregrinus sp. nov.}

Type material. Holotype from Brazil, Paraná: Paranaguá (Ilha

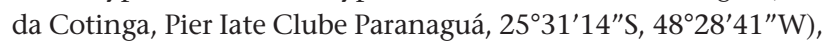
1 colony, 30/III/2010, L.P. Kremer leg. (MZUSP00030). Paratype, BrazIL, Paraná: Paranaguá (Ilha da Cotinga, Ponta da Cruz, 25³0'S; $48^{\circ} 29^{\prime} \mathrm{W}$ ), many colonies, 13/I/2010, R. Metri leg.(DZUP SID 01).

Description. Colonies dark brown or green, cushion like, diameter ranging between 0.5 and $7.0 \mathrm{~cm}, 3 \mathrm{~cm}$ high. Colonies mainly on the underside of rocks, but also on the sides of rocks and as epifauna. Colonies with 1-5 lobes, closely clumped, and attached by the entire basal area or by a common smaller area (Figs 2 and 3). Zooids arranged in round systems with yellowish atrial languets converging to round common cloacal apertures, or arranged along short channels that converge at the cloaca. In some specimens, up to six delicate filament-like test projections arising from the cloacal edge. Tests gelatinous, translucent internally, may have sand in the superficial, but not internal, layer. Zooids about $6 \mathrm{~mm}$ long, comprising the $3 \mathrm{~mm}$ thorax, $1.5 \mathrm{~mm}$ abdomen and $1.5 \mathrm{~mm}$ posterior abdomen (Fig. 4). Conical, six lobed oral aperture with triangular lobes; atrial aperture lateral projecting upwards, conical with plain margin. Conspicuous sphincter around the base in both apertures. Dorsal languet extending between the two siphons; usually long and straight with a toothed edge, but also narrow and pointed or bifurcate. Longitudinal muscle fibers extending along the entire languet, ramifying closer to the distal end, forming transverse fibers. Small projection occasionally posterior to the atrial aperture. Seven to ten thin longitudinal fiber muscles (some branched) along the anterior two thirds of the thorax. No transverse muscle fibers. More than 30 tentacles of three orders forming one circle. Dorsal tubercle small and tubular. Pharynx with 10 to 12 rows of stigmata with 13 to 15 stigmata in each half row. Transverse vessels not undulate. Dorsal lamina formed by languets displaced to the left of the central dorsal line. Abdomen in vertical position lined with the thorax. Esophagus reaching the stomach laterally. Stomach oval and smooth-walled. Cup-shaped constriction clearly visible between the end of the duodenum and the intestinal loop, without rectal caecum. Bilobed anus at the level of the fourth or fifth row of stigmata. Posterior abdomen not very elongated, oval, and joined to the abdomen by a narrow neck; with numerous ( $>30$ ) testicular follicles. Wide posterior cardiac region, in some specimens as large as the testicular area. Ovary with about 15 oocytes of different sizes (three or four large) at about the ninth or tenth row of stigmata in the thorax. Large number of embryos, some individuals $>25$, incubated in the atrial cavity in the right side 

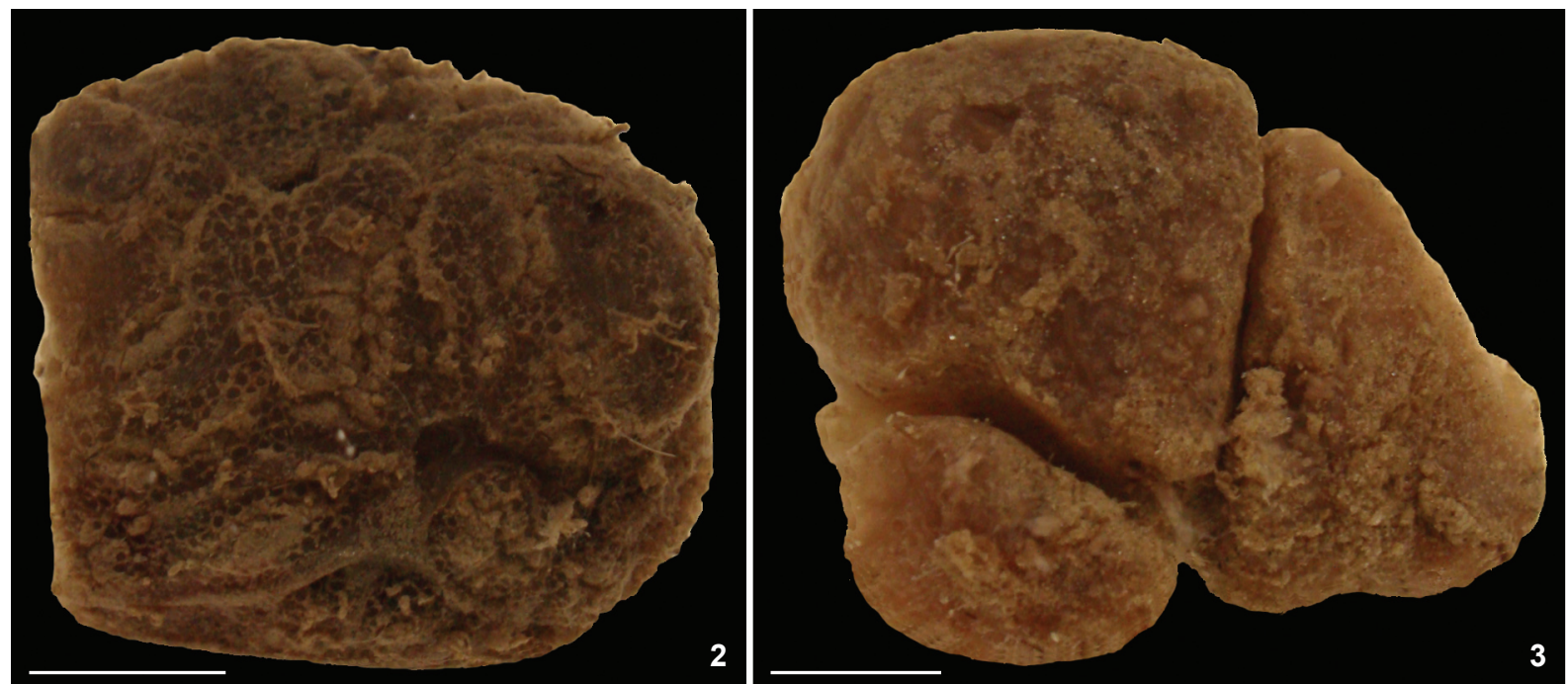

Figures 2-3. Upper surface of the preserved colonies of Sidneioides peregrinus sp. nov. showing variation in colony shape. Scale bars: $1 \mathrm{~cm}$.

of the thorax. Larvae oval with a $0.65 \mathrm{~mm}$ long trunk (Fig. 5). Tail wound around the trunk at $\geqslant 3 / 4$ length, sometimes reaching almost a full circle. Four club-shaped ectodermal ampullae in each side and three, linear and evenly spaced, adhesive papillae with thin stalks. Two clusters of ectodermal vesicles, one postero-ventral (around 15 vesicles) and another antero-dorsal (around eight vesicles), between the ampullae and the oral siphon. Both a statocyte and ocellus in the sensory vesicle.

Etymology. From Latin, traveling about, foreign.

Remarks. The type species, $S$. tamaramae, differs from $S$. japonense and $S$. snamoti in several aspects and is most similar to $S$. peregrinus sp. nov. Both $S$. peregrinus sp. nov. and $S$. tamaramae differ from $S$. japonense and $S$. snamoti in that the latter two species have flatter colonies, longer zooids, larger number of rows of stigmata, and thoracic musculature not restricted to the thorax, converging into two muscle bands that extend along the left side of the abdomen (ТокIoka 1953, MiLlar 1975, Nishikawa 1990). Despite the similarity between $S$. tamaramae and $S$. peregrinus sp. nov. they also differ in several ways. In S. tamaramae, described from New South Wales (Котт 1992), the colony forms smaller lobes than $S$. peregrinus sp. nov., and is somewhat mushroom shaped. Most colonies of $S$. tamaramae have many narrow pedunculated lobes joined by a basal tunic, each containing one central cloacal projection. Contrastingly, in S. peregrinus sp. nov. several cloacal apertures lie on the colony surface of each, wide, lobe. In S. tamaramae the ovary is in the anterior part of the thorax at the level of the anal opening, while in S. peregrinus sp. nov. it is posterior to the anal opening at about the ninth or tenth row of stigmata. The body wall musculature of $S$. tamaramae is restricted to the first third of the thorax, while in S. peregrinus sp. nov. it extends along the anterior two thirds of the thorax. Sidneioides

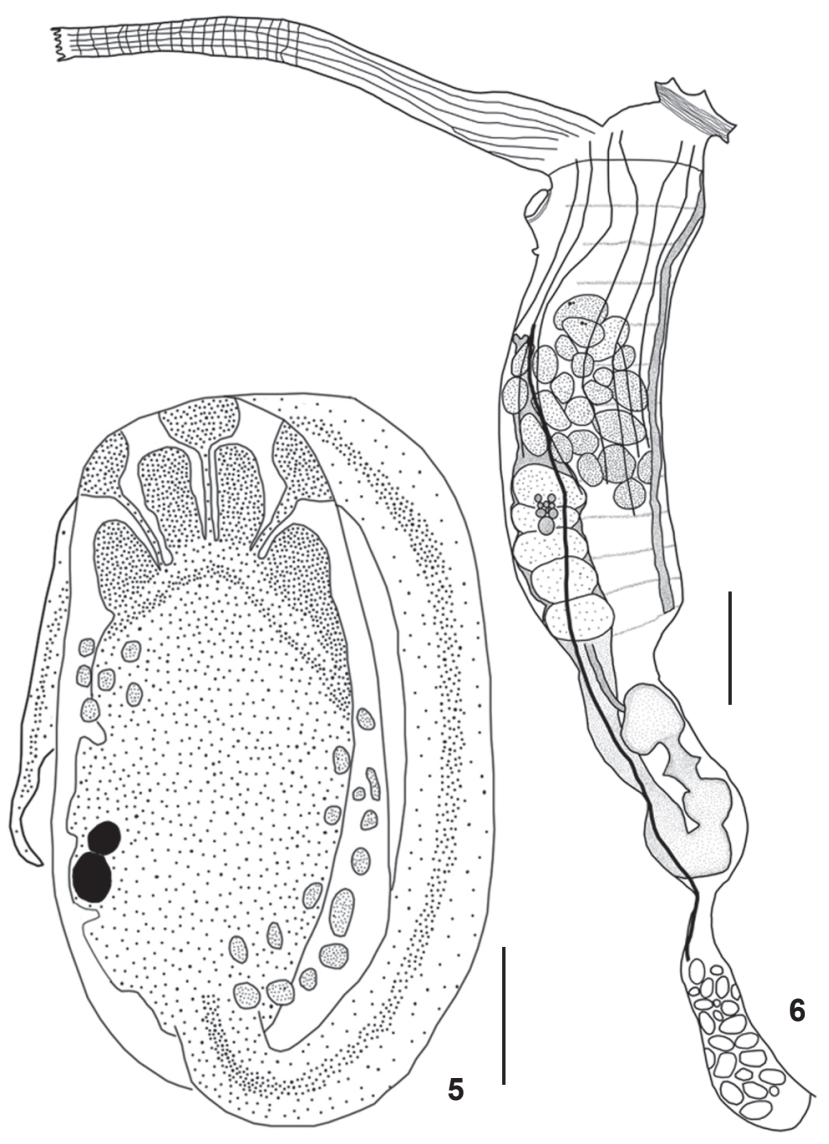

Figures 4-5. Sidneioides peregrinus sp. nov.: (4) zooid; (5) larva. Scale bars: $4=1 \mathrm{~mm}, 5=0.1 \mathrm{~mm}$. 
tamaramae tends to have more rows of stigmata (12-14) than $S$. peregrinus sp. nov. (10-12). The larvae of $S$. tamaramae are smaller with the larval trunk of about $0.4 \mathrm{~mm}$ in length, and have longer and thinner ectodermal ampullae (Котт 1992). In spite of the variation in colony shape in $S$. tamaramae considered by Котт (1992) the differences described here support the new species for the specimens found in Paranaguá Bay.

\section{DISCUSSION}

We propose that this new species is an introduction to the Brazilian coast based on different lines of evidence: it was never found in previous surveys in the region, it has a restricted local distribution, the type locality is extremely close to a major international port and, perhaps most importantly, the genus has never been found in the Atlantic Ocean. While individually, these reasons are not sufficient, together they offer strong support for this proposal, similarly to the simultaneous presence of many different criteria that have been used to detect introductions (CHAPMAN \& CARLTON 1991, 1994).

During several surveys in Paranaguá Bay and neighboring areas and colonization experiments on polyethylene plates, $S$. peregrinus sp. nov. was only found at Cotinga Island (Rосна \& Nasser 1998, Rocha \& Faria 2005, Rocha \& Kremer 2005, Cangussu et al. 2010). The high density of colonies and the many larvae within the colonies indicate that the species is probably not rare and that it is reproducing. If it were native, it would have been found on other suitable substrates in the region. The type locality borders the channel with intense ship traffic at the port of Paranaguá (also in the bay), one of the most important international ports in southern Brazil. Thus the introduction of $S$. peregrinus sp. nov. is likely to be the result of the ship traffic. Ascidians, as sessile marine organisms, have been documented to be passively transported attached on recreational boats and ships. Today, non-native ascidians are increasingly being reported from around the world (Lambert 2007, Shenkar \& Swalla 2011).

The phylogenetic criteria also applies to this species (Chapman \& Carlton 1991, 1994). Sidneioides has never been found outside of the western Pacific Ocean, unless S. ivicense is truly in this genus. However, the specimens analyzed by Pérès (1957) were immature and the author was unable to see the only apomorphy of the genus (the ovary in the thorax). The fact that the atrial languet was absent in those specimens argues against their placement in Sidneioides, given that it is present in all other species in the genus. Sidneioides tamaramae was registered on the west coast of Australia (Котт 1992), S. japonense occurs in Japan coast and the Banda Sea (Indonesia) and S. snamoti is also in Japan (NishiкAWA 1990, ТокіокA 1953, Millar 1975). This distribution pattern, and the fact that all five other genera in Polyclinidae have Atlantic representatives (although fewer in number than in the Pacific) suggests that Sidneioides is native to the western Pacific and the absence of any sister group of $S$. peregrinus in the Atlantic is additional evidence that its presence in Paranaguá Bay is not the result of natural biogeographic processes.

In conclusion, evidence strongly suggests that $S$. peregrinus sp. nov. is an introduced species in Brazil. This is not the first time that a species is described from its introduced location before its true origins were discovered, for example, CARLTON (2009) listed more than 20 species with this pattern (his "pseudoindigenous species"). Sidneioides peregrinus sp. nov. is very similar to Polyclinum constellatum Savigny, 1816 in external morphology, and with which it may be easily confused. Because $P$. constellatum also has a widespread distribution in all warm oceans and is very common in ports and impacted regions (RосHA et al. 2009, Marins et al. 2010), samples should be carefully dissected to confirm identification. Given the great abundance of $S$. peregrinus sp. nov. in Cotinga Island and the intense reproductive activity observed, more studies are needed to check the present distribution of this species in Paranaguá Bay and evaluate its potential for invasion. These types of studies are fundamental if we wish to prevent new introductions that may result in ecological and economic problems here and elsewhere around the world.

\section{ACKNOWLEDGMENT}

We thank the staff of the Paranaguá Yacht Club for logistics in Paranaguá, Ana Paula R. Rigo, Aline S. Kloh and Leonardo M. Hostin, for field assistance, James Roper for the English text revision, and two anonymous reviewers that improved the text. Conselho Nacional de Desenvolvimento Científico e Tecnológico (CNPq) granted a scholarship to LPK (Doctoral program in Ecology and Conservation, Universidade Federal do Paraná) and a research grant to RMR.

\section{LITERATURE CITED}

Cangussu, L.C.; L. Altvater; M.A. Haddad; A.C. Cabral; H.L. Heyse \& R.M. Rосна. 2010. Substrate type as a selective tool against colonization by non-native sessile invertebrates. Brazilian Journal of Oceanography 58: 219-231.

Carlton, J. 2009. Deep invasion ecology and the assembly of communities in historical time, p. 13-56. In: G. RiLov \& J. A. Crooks (Eds). Biological Invasions in Marine Ecosystems. Heidelberg, Springer-Verlag, 642p.

Chapman, J.W. \& J.T. Carlton. 1991. A test of criteria for introduced species: The global invasion by the isopod Synidotea laevidorsalis (Miers, 1881). Journal of Crustacean Biology 11 (3): 386-400.

Chapman, J.W. \& J.T. Carlton. 1994. Predicted discoveries of the introduced isopod Synidotea laevidorsalis (Miers, 1881). Journal of Crustacean Biology 14 (4): 700-714.

Harant, H. 1929 Ascidies provenant des croisieres du Prince Albert Premier de Monaco. Résultats des Campagnes Scientifiques du Prince de Monaco 75: 1-112. 
Kotт, P. 1985. The Australian Ascidiacea part 1, Phlebobranchia and Stolidobranchia. Memoirs of the Queensland Museum 23: $1-440$.

Котт, P. 1992. The Australian Ascidiacea part 3, Aplousobranchia (2) and Supplement (2). Memoirs of the Queensland Museum 32: 375-655.

LAMBERT, G. 2007. Invasive sea squirts: a growing global problem. Journal of Experimental Marine Biology and Ecology 342: 3-4.

Lana, P.C.; E. Marone; R.M. Lopes \& E.C. Machado. 2001. The Subtropical Estuarine Complex of Paranaguá Bay, Brazil, p. 131-145. In: U. Seeliger \& B. KJerfve (Eds). Coastal Marine Ecosystems of Latin America. Berlin, Springer-Verlag, 360p.

Marins, F.O.; R.L.M. Novaes; R.M. Rocha \& A.O.R. Junqueira. 2010. Non indigenous ascidians in port and natural environments in a tropical Brazilian bay. Zoologia 27 (2): 213-221.

Millar, R.H. 1975. Ascidians from the Indo-West-Pacific region in the Zoological Museum, Copenhagen (Tunicata, Ascidiacea). Steenstrupia 3: 205-336.

Monniot, C.; F. Monniot \& P. Laboute. 1991. Coral reef ascidians of New Caledonia. Paris, Orstom Editions, Coléction Faune
Tropicale XXX, 247p.

NishikaWA, T. 1990. The ascidians of the Japan Sea I. Publications of the Seto Marine Biological Laboratory 34: 73-148.

Pérès, J.M. 1957. Ascidies récoltées dans les parages des Baléares par la "Professor Lacaze-Duthiers" (Deuxième partie: Iviza et San Antonio). Vie et Milieux 6: 223-234.

Rocha, R.M. \& S.B. Faria. 2005. Ascidians at Currais Islands, Paraná, Brazil: taxonomy and distribution. Biota Neotropica 5: 1-20.

Rocha, R.M. \& L.P. Kremer. 2005. Introduced ascidians in Paranaguá Bay, Paraná, southern Brazil. Revista Brasileira de Zoologia 22: 1170-1184.

Rocha, R.M. \& C.M. Nasser. 1998. Some ascidians (Tunicata, Ascidiacea) from Paraná State, southern Brazil. Revista Brasileira de Zoologia 15: 633-642.

Rocha, R.M.; L.P. Kremer; M.S. Baptista \& R. Metri. 2009. Bivalve cultures provide habitat for exotic tunicates in southern Brazil. Aquatic Invasions 4: 195-205.

Shenkar, N. \& B.J. Swalla. 2011. Global diversity of Ascidiacea. PLoS ONE 6 (6): e20657.

Токіока, Т. 1953. Ascidians of Sagami Bay. Tokyo, Iwanami Shoten, 515p.

Submitted: 21.IV.2011; Accepted: 19.X.2011.

Editorial responsibility: Marcos D.S. Tavares 